\title{
Zinc Sulphate and Nano-Zinc Oxide Effects on Some Physiological Parameters of Rosmarinus officinalis
}

\author{
Sasan Mohsenzadeh, Seyedeh Sara Moosavian \\ Department of Biology, Faculty of Sciences, Shiraz University, Shiraz, Iran \\ Email: mohsenzadeh@susc.ac.ir
}

How to cite this paper: Mohsenzadeh, S. and Moosavian, S.S. (2017) Zinc Sulphate and Nano-Zinc Oxide Effects on Some Physiological Parameters of Rosmarinus officinalis. American Journal of Plant Sciences, 8, 2635-2649.

https://doi.org/10.4236/ajps.2017.811178

Received: August 15, 2017

Accepted: October 9, 2017

Published: October 12, 2017

Copyright $\odot 2017$ by authors and Scientific Research Publishing Inc. This work is licensed under the Creative Commons Attribution International License (CC BY 4.0).

http://creativecommons.org/licenses/by/4.0/

\begin{abstract}
In the present study, the effects of foliar application of zinc sulphate and nano-zinc oxide on physiological indices (chlorophyll and carotenoids content, antioxidant activity, total phenolic content, proline, lipid peroxidation and sugar) of rosemary were evaluated. Greenhouse cultivation experiment in a randomized complete block with three levels of foliar zinc and three levels of foliar nano-zinc oxide and control treatment, each with three replications, was carried out. The results showed that low concentrations of zinc and nano-zinc oxide significantly increased chlorophyll and carotenoid compared to the control. Whereas with the high concentration of nano-zinc oxide, chlorophyll and carotenoid decreased compared to the control. Antioxidant enzymes activity increased with zinc and nano-zinc oxide compared to control plants. In addition, proline, membrane lipid peroxidation, soluble sugar and phenolic compounds increased in the treated plants. Proline and plant antioxidant enzymes to scavenge free radicals have increased. Two levels of zinc increased the total phenolic compounds of rosemary leaves significantly but nano-zinc oxide did not show a significant difference compared to the control.
\end{abstract}

\section{Keywords}

Nanoparticle, Physiological Response, Rosemary, Zinc

\section{Introduction}

Low efficiency of soil absorption of some micronutrients by plant is economically very costly, and hence alternative methods such as spraying can be used [1]. Some fertilizer can be sprayed on the leaves and stems of the plant [2]. Foliar application can access nutrients for plants to achieve high performance guarantee [3] 
[4]. Zinc is an important nutrient for plants that is absorbed in the form of divalent cations and has various physiological roles in higher plants and is involved in the metabolism of proteins, carbohydrates, nucleic acids and lipids, photosynthesis and biosynthesis of auxin [5] [6]. This element is used as part of the structure of enzymes or acts as regulator cofactors in a number of enzymes. Research has shown that $\mathrm{Zn}$ is used in the building of at least four enzymes: carbonic anhydrase, $\mathrm{Cu}-\mathrm{Zn}$ superoxide dismutase, alcohol dehydrogenase, RNA polymerase. Other enzymes have been discovered that need $\mathrm{Zn}$ for activity, the most important of these enzymes include alcohol dehydrogenase, aldolase, trans-phosphorylase, DNA and RNA polymerase [7]. In plants that have Zn deficiency, reduced protein synthesis will occur [7]. Ribosomes are broken without $\mathrm{Zn}$ but with $\mathrm{Zn}$ consumption the building dates back to the first case. $\mathrm{Zn}$ is essential to build indole acetic acid (IAA) and excessive concentration of tryptophan in the leaves of plants that have $\mathrm{Zn}$ deficiency is probably caused by this problem [7]. Zinc absorption by plant is done with both active and passive mechanisms. Passive absorption takes place through electrostatic adsorption ions on the root cells cell wall. Active absorption is influenced more by temperature and ventilation root and it seems that active absorption mechanism is a major supplier of the $\mathrm{Zn}$ that plants require. Due to slow absorption of zinc and other similar elements through root it is better that these elements be placed at the disposal plant through aerial parts [1]. Although there is little need of $\mathrm{Zn}$ for plants (5 - $100 \mathrm{mg} \cdot \mathrm{kg}^{-1}$ ), but if enough of this element is not available plants suffer physiological stress resulting from the inefficiency of multiple enzyme systems and other metabolic actions related to $\mathrm{Zn} \mathrm{[8].} \mathrm{The} \mathrm{results} \mathrm{of} \mathrm{research} \mathrm{in} \mathrm{the}$ field of zinc suggest that the use of this element in different stages of plant growth can affect plant performance in different ways [9]. Zinc plays an important role in the regulation of stomatal opening, because this element is involved in the maintenance of potassium in stomatal guard cells [10]. Zinc nutrient element is involved as cofactors in the activation of many enzymes on the biosynthetic pathway of secondary metabolites [8]. Nanotechnology is accurate and controlled manipulation of atomic or molecular structure of materials to produce nanoscale tiny particles with new features and special applications [11]. Nanometals features with more contact area and high surface energy may be totally different from characteristics of base metals [12]. Conversion of the material to the nanoscale changes the physical, chemical, biological features and catalytic activities of them and the addition of higher solubility, capable of penetrating the cell membrane and chemical activity in these nanoparticles emerges [12]. In recent years, nanoparticles oxidized elements, such as nano zinc oxide are used in different cases [13]. Studies have shown that nanoparticles compared to metal ions have higher toxicity to allow them to penetrate the cell membrane and release metal ions inside the cell [14]. Increasing the concentration of $\mathrm{Zn}$ in corn has been reported with the use of zinc sulfate [15]. Rosemary, with the scientific name Rosmarinus officinalis belongs to the family of Lamiaceae [16]. Rosemary is the plant that is shrub, perennial, evergreen and with height of 1 to 
2 meters, with erect branches, and sometimes lying on the ground with green color, brown and fragrant, leaves are opposite, narrow, long, sharp and slightly rough bent backward, leaves are without hairs but in some varieties, green leaves and white hairs and cotton is covered behind it. Leaves are without petiole and flowers are arranged in clusters along the axis. The flowers are usually white to pink or white and occasionally purple that appears in late spring. Four nut fruit with brown color, firm, round and its egg is small inside the fruit. All leaves, blossoms and scented members are aromatic [17]. Rosemary is native to the Mediterranean region well-calcareous areas that tolerate arid and semi-arid hot weather [17]. Rosemary components are very important in various industries, due to its numerous properties, including convenient and good odor which is emitted as a sedative, food preservative, preservatives, colors and flavors of food and very potent antioxidant that has high consumption [18]. The aim of this research is study of the effect of zinc sulphate and nano zinc oxide on some physiological parameters of $R$. officinalis.

\section{Materials and Methods}

\subsection{Seedling Preparation}

Rosemary seedling was purchased from greenhouse Ghasroldashti in Shiraz. Similar plants were put in pots arranged in the greenhouse. The pots were randomly labeled.

\subsection{Treatments Preparation}

Zinc oxide nanoparticles were prepared from Nanosany Company (Mashhad, Iran). The particle size of zinc oxide was about $10-30 \mathrm{~nm}$ with $99 \%$ purity and $6.5 \mathrm{~g} / \mathrm{cm}^{3}$ density with white color and almost spherical morphology. Then, zinc concentrations (2, 4 and 6 grams per thousand) and nano-zinc (1, 4 and 7 grams per thousand) were prepared in the laboratory. The pots were irrigated $50 \mathrm{ml}$ for 4 weeks every other day. The minimum and maximum temperatures in greenhouse were $32 \pm 3$ and $38 \pm 3$ centigrade. Treatments were applied as spray on plants three times over a period of three weeks. At the end, the plants were harvested and frozen in liquid nitrogen.

\subsection{Chlorophyll and Carotenoids Measurements}

Chlorophyll was measured using Arnon method [19]. Two hundred mg of the leaves were weighed and $80 \%$ acetone was added and centrifuged at $4800 \mathrm{rpm}$ for $20 \mathrm{~min}$. The above solution was used to measure chlorophyll and carotenoids. The Shimadzu UV-160A model spectrophotometer was adjusted at wavelengths of 645 and $663 \mathrm{~nm}$ for chlorophyll and at wavelengths of 412, 431, 460 and $480 \mathrm{~nm}$ for carotenoids.

\subsection{Proline Measurement}

Bates method was used for measure of proline [20]. Two hundred mg of the 
leaves was weighed, and then $10 \mathrm{ml}$ sulfosalicylic acid $3 \%$ was added. After 48 hours, $2 \mathrm{ml}$ of the above solution with $2 \mathrm{ml}$ ninhydrin and $2 \mathrm{ml}$ of acetic acid were added and heated for one hour in a hot water bath at $78^{\circ} \mathrm{C}$. After cooling on ice, $4 \mathrm{ml}$ of toluene was added and vortexed for 20 seconds. Finally, the upper phase containing red complex was used to measure the proline at a wavelength of $520 \mathrm{~nm}$ by a spectrophotometer (Shimadzu UV-160A Model, Japan).

\subsection{Soluble Sugars Measurement}

Soluble sugars were measured according to the Nelson method [21]. In this experiment, a solution of $70 \%$ ethanol, distilled water, chloroform, alkaline copper reagent and arsenomolybdate were used. Two hundred mg of plant tissue was placed in tubes and $10 \mathrm{ml}$ of sulfosalicylic acid 3\% were added. After 48 hours, $0.9 \mathrm{ml}$ of distilled water and $1 \mathrm{ml}$ alkaline copper solution were added to $0.1 \mathrm{ml}$ of solution and healed in water bath for 20 minutes at $78^{\circ} \mathrm{C}$. After cooling, $1 \mathrm{ml}$ of arsenomolybdate and $7 \mathrm{ml}$ of distilled water was added to each tube and mixed by vortex. Light absorption spectrophotometer UV-160A Model Japan was used at wavelength of $520 \mathrm{~nm}$ and soluble sugars were determined using a standard curve.

\subsection{Total Phenolic Compounds Measurement}

The amount of total phenolic compounds using the Folin-Ciocalteu was performed according to the method of Kim and co-workers [22]. In this experiment, the methanol extract of leaves of plants, $100 \%$ ethanol, $50 \%$ methanol, reagent Folin-Ciocalteu, Sodium bicarbonate $6 \%$ and Gallic acid standard solution were used. Five $\mathrm{ml}$ Folin-Ciocalteu reagent and $45 \mathrm{ml}$ of distilled water were added. Two hundred microliters of different concentrations were added to test tubes containing $1500 \mathrm{ml}$ of the diluted Folin-Ciocalteu reagent and the samples were analyzed for 5 minutes at room temperature. Then, 1500 microliters sodium bicarbonate $6 \%(\mathrm{vw})$ was added to the solution. The samples were placed for 130 minutes at room temperature. Absorbance of the samples was measured at $750 \mathrm{~nm}$ wavelength.

\subsection{Total Antioxidant Measurement}

The antioxidant potential of using the stable radical DPPH was performed according to the method described by Shimada and co-workers [23]. The methanol extraction of the plant, by using methanol, $0.004 \% \mathrm{DPPH}$ in methanol and Trolox solution were carried out. The $0.024 \mathrm{~g}$ DPPH was dissolved in $100 \mathrm{ml}$ of methanol. Then, $150 \mathrm{ml}$ of methanol extracts of different concentrations was added to $2850 \mathrm{ml} 0.004 \%$ DPPH in methanol and placed in the dark for one hour. Total antioxidant was measured by spectrophotometer at $515 \mathrm{~nm}$ wave length.

\subsection{Lipid Peroxidation Measurement}

The membrane lipid peroxidation was performed by Heath and Packer method 
[24] based on complex formation of malondialdehyde (MDA). Leaf tissue (0.3 g) was homogenized in $10 \mathrm{ml}$ TCA $0.1 \%$ and then centrifuged for $15 \mathrm{~min}$ at 10,000 $\mathrm{rpm}$. One $\mathrm{ml}$ of the supernatant was added to $4 \mathrm{ml}$ TCA $20 \%$ containing TBA $0.5 \%$, then mixed and boiled in water bath at temperature of $95^{\circ} \mathrm{C}$. After $30 \mathrm{mi}-$ nutes the tubes were placed in crushed ice and then centrifuged for ten minutes at $10,000 \mathrm{rpm}$. The light absorption at a wavelength of $532 \mathrm{~nm}$ was measured. Absorption conflicting compounds were measured at wavelength of $600 \mathrm{~nm}$ and for absorption correction, were deducted of the absorbance at $532 \mathrm{~nm}$. The membrane lipid peroxidation was calculated using the equation $\mathrm{A}=\varepsilon \mathrm{bc}$ extinction coefficient vs. TBA-MDA complex $105 \times 1 / 56$.

\subsection{Statistical Analysis}

This experiment was performed in a completely randomized design with 7 treatments ( 3 levels of zinc and 3 levels of nano zinc oxide) with 3 replicates and each pot was one replicate. The data were analyzed using ANOVA by SPSS16 software and mean comparison at 5 percent was calculated by Duncan test.

\section{Results}

\subsection{Chlorophyll and Carotenoids}

The results showed that the application of zinc changed the total chlorophyll significantly (Figure 1). Mean comparisons showed the highest chlorophyll was found at concentration of 4 and 6 gr per thousand zinc (SB and SC) compared to the control. Nano zinc oxide did not change the chlorophyll, significantly. The highest total carotenoid was found at concentration of 1 and 4 gr per thousand

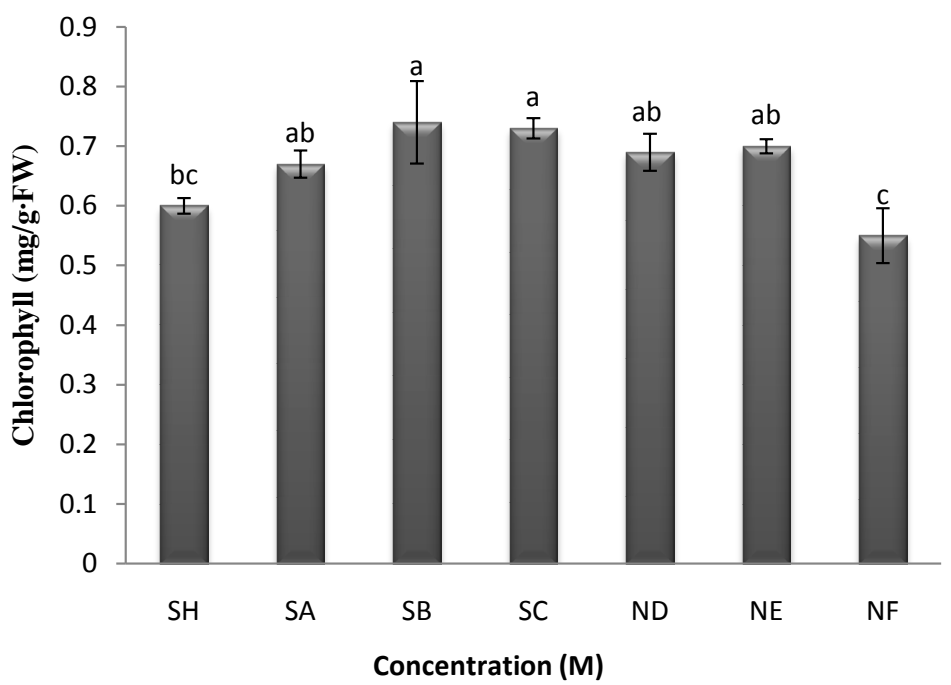

Figure 1. Chlorophyll at various levels of zinc and nano zinc oxide of rosemary leaves. SH (control), SA, SB and SC are concentrations of 2, 4 and 6 g per thousand zinc, respectively. ND, NE and NF are concentration of 1,4 and $7 \mathrm{~g}$ per thousand nano zinc oxide, respectively. The different letters means statistically significant, at 0.05 by Duncan test. 
nano zinc oxide. The zinc treatments did not increase carotenoid significantly (Figure 2).

\subsection{Membrane Lipid Peroxidation}

The results showed that only 4 and 7 gr per thousand nano zinc oxide increased membrane peroxidation significantly (Figure 3 ). The highest amount of peroxidation of membrane lipids was found at concentration of 7 gr per thousand nano

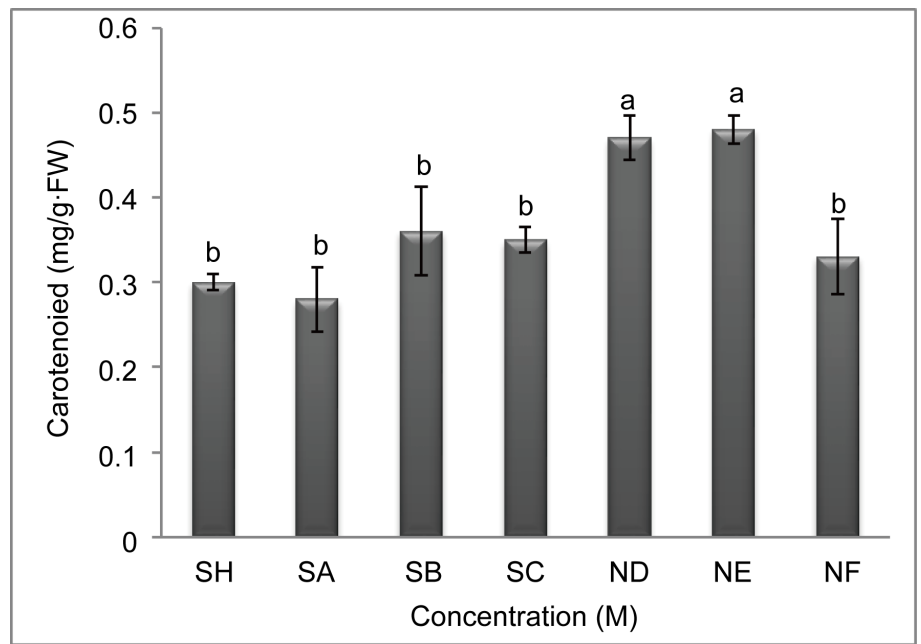

Figure 2. The carotenoids in different levels of zinc and nano zinc oxide of rosemary leaves. SH (control), SA, SB and SC are concentrations of 2, 4 and $6 \mathrm{~g}$ per thousand zinc, respectively. ND, NE and NF are concentrations of 1,4 and $7 \mathrm{~g}$ per thousand nano zinc oxide, respectively. The different letters means statistically significant, at 0.05 by Duncan test.

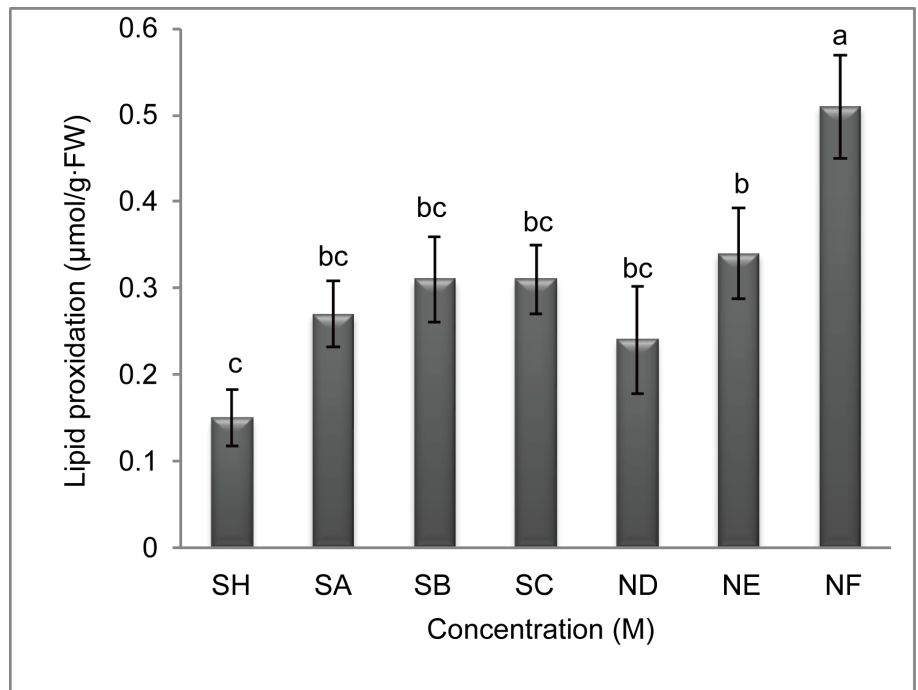

Figure 3. The membrane lipid peroxidation at different levels of zinc and nano zinc oxide nanoparticles of rosemary leaves. SH (control), SA, SB and SC are concentrations of 2, 4 and $6 \mathrm{~g}$ per thousand zinc, respectively. ND, NE and NF are concentrations of 1,4 and $7 \mathrm{~g}$ per thousand nano zinc oxide, respectively. The different letters means statistically significant, at 0.05 by Duncan test. 
zinc oxide (NF), which was significantly different from 4 gr per thousand nano zinc oxide (NE).

\subsection{Leaf Proline Content}

The results showed that the 6 gr per thousand zinc sulfate and 4 and 7 gr per thousand nano zinc oxide increased proline of rosemary leaves (Figure 4). The highest amount of proline was for 7 grams per thousand nano zinc oxide (NF) which was significantly different from other concentrations. In addition, proline of $4 \mathrm{gr}$ in thousand nano zinc oxide treatment was significantly higher than $6 \mathrm{gr}$ per thousand zinc.

\subsection{Soluble Sugar Content}

The 6 gr per thousand zinc and 4 and 7 gr per thousand nano zinc oxide increased the soluble sugar content of rosemary significantly (Figure 5). The highest amount of soluble sugar was for 7 gr per thousand nano zinc oxide (NF).

\subsection{Total Phenolic Compounds}

The 4 and 6 gr per thousand zinc increased the total phenolic compounds of rosemary leaves significantly (Figure 6). Concentrations of 1, 4 and 6 gr per thousand nano-ZnO did not show a significant difference compared to control.

\subsection{Total Antioxidant Potential}

The 4 and 6 gr per thousand zinc treatments increased the total antioxidant of rosemary leaves significantly compared to control (Figure 7). The nano zinc oxide did not show any significant increases in total antioxidant.

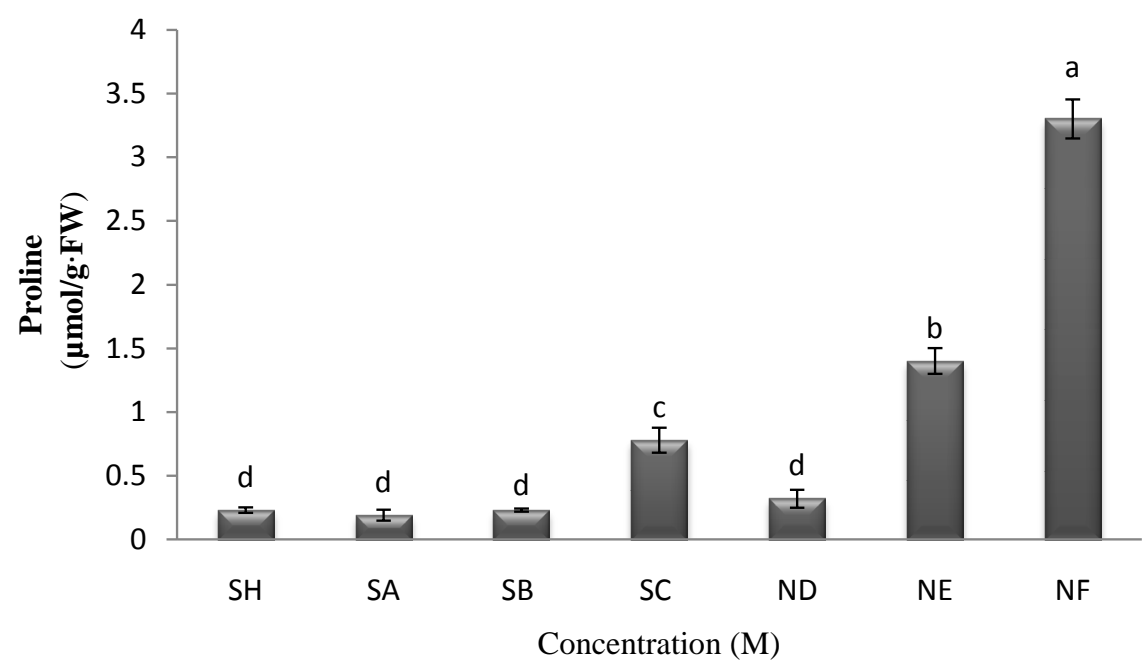

Figure 4. Effect of zinc sulfate and zinc oxide nanoparticles on proline of rosemary leaves. SH (control), SA, SB and SC are concentrations of 2, 4 and $6 \mathrm{~g}$ per thousand zinc, respectively. ND, NE and NF are concentrations of 1,4 and $7 \mathrm{~g}$ per thousand nano zinc oxide, respectively. The different letters means statistically significant, at 0.05 by Duncan test. 


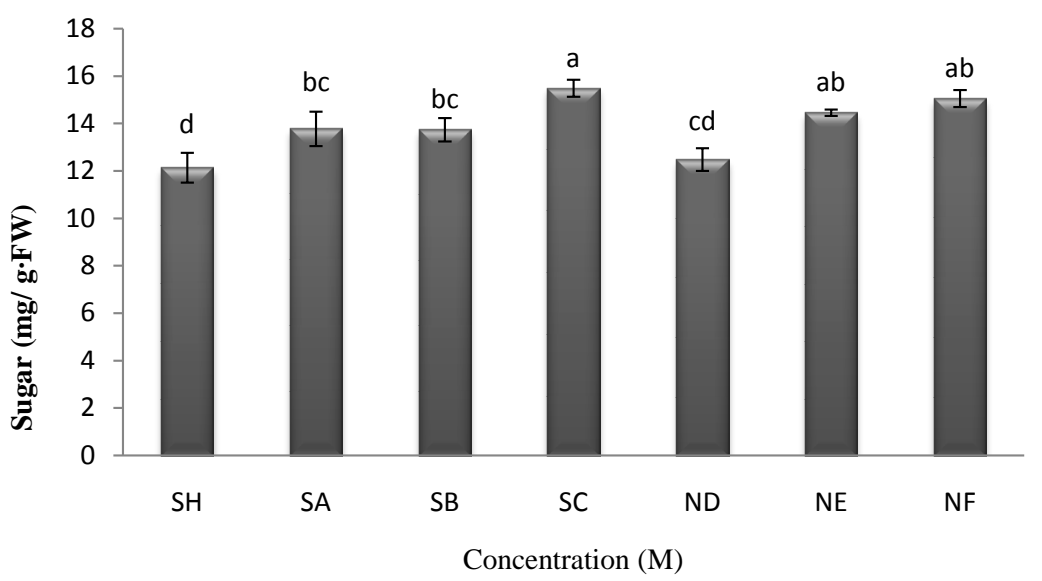

Figure 5. Effect of zinc sulfate and zinc oxide nanoparticles on the soluble sugars content of rosemary leaves. SH (control), SA, SB and SC are concentrations of 2, 4 and 6 g per thousand zinc, respectively. ND, NE and NF are concentrations of 1, 4 and $7 \mathrm{~g}$ per thousand nano zinc oxide, respectively. The different letters means statistically significant, at 0.05 by Duncan test.

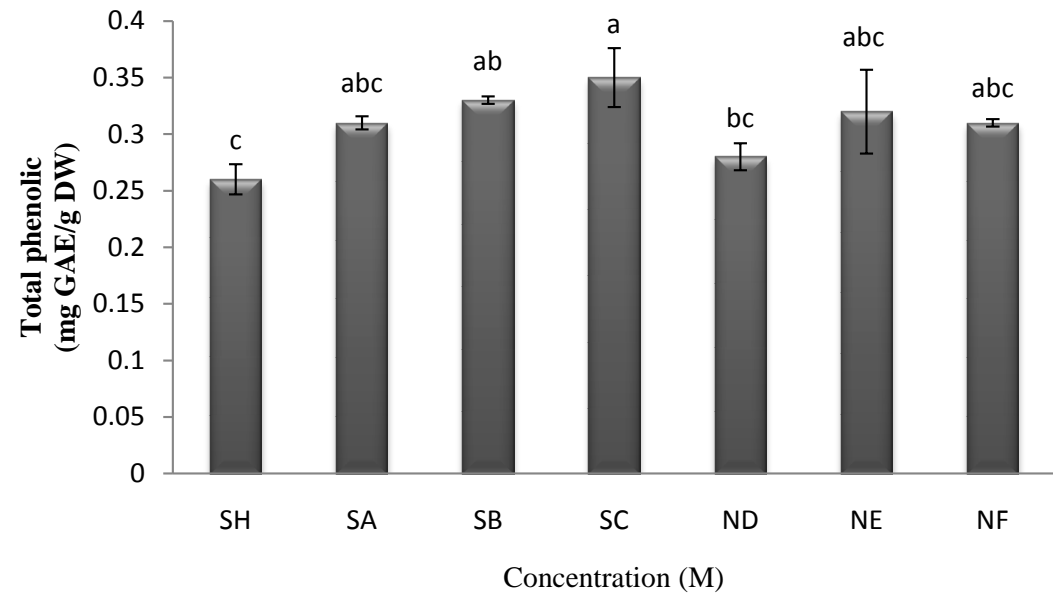

Figure 6. The total phenolic compounds of rosemary leaves at different concentration of zinc and nano zinc oxide. SH (control), SA, SB and SC are concentrations of 2, 4 and $6 \mathrm{~g}$ per thousand zinc, respectively. ND, NE and NF are concentrations of 1,4 and $7 \mathrm{~g}$ per thousand nano zinc oxide, respectively. The different letters means statistically significant, at 0.05 by Duncan test.

\section{Discussion}

\subsection{Chlorophyll and Carotenoids}

In a study on safflower, spraying of zinc increased chlorophyll, which illustrates the significant role of zinc in the metabolism of the nitrogen element and chlorophyll production [25]. Zinc by protection of sulfhydryl groups caused synthesized chlorophyll [26]. In the presence of zinc, completion and the formation of chlorophyll is finally facilitated. Of course, the zinc element in the formation of chlorophyll is not effective directly, but may be effective on concentration of food elements involved in the formation of chlorophyll or substances that are part of the chlorophyll molecule such as iron and magnesium. In fact, zinc is 


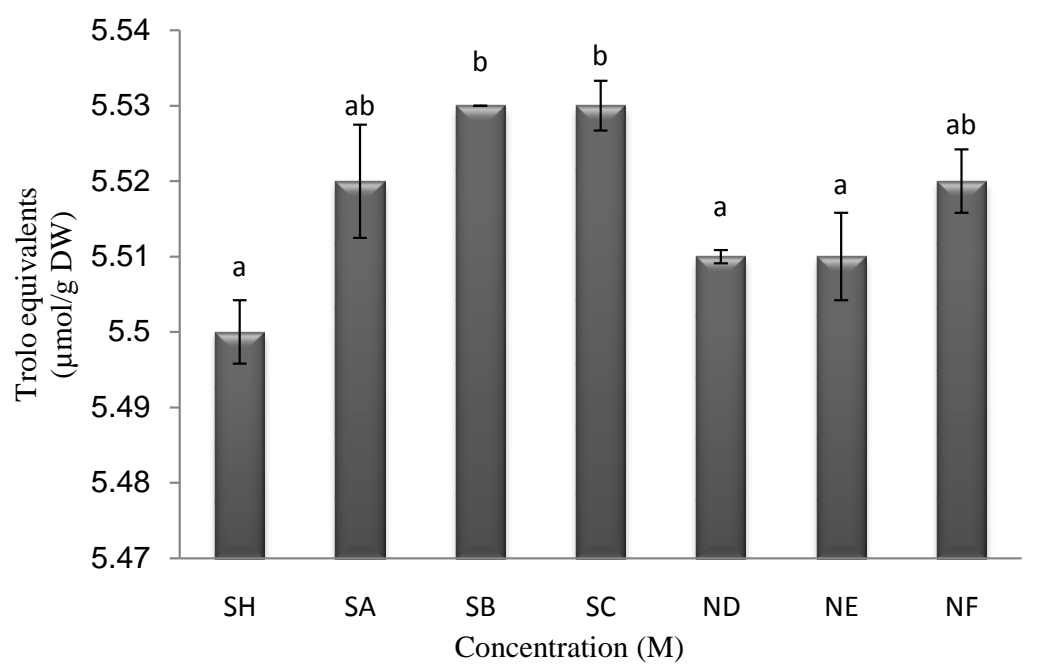

Figure 7. The antioxidant potential of rosemary leaves at different concentrations of zinc sulphate and nano zinc oxide. SH (control), SA, SB and SC are concentrations of 2, 4 and $6 \mathrm{~g}$ per thousand zinc sulphate, respectively. ND, NE and NF are concentrations of 1, 4 and $7 \mathrm{~g}$ per thousand nano zinc oxide, respectively. The different letters means statistically significant, at 0.05 by Duncan test.

required for the activity of enzymes that are involved in chlorophyll biosynthesis [27]. The results of Behtash and colleagues on red beet embryo show that zinc not only, prevented destruction of chlorophyll by cadmium but had a significant effect on chlorophyll index and taking on increased chlorophyll content compared to the control treatment [28]. $\mathrm{Zn}$ is a heavy element and like other heavy metals, in large quantities, is toxic to many plants, including rosemary, and degradation of chlorophyll in these circumstances is obvious. It seems that created toxicity, in addition to preventing the absorption of essential elements in the biosynthesis of chlorophyll ( $\mathrm{Mg}$ and $\mathrm{Fe}$ ), triggered stimulation of the chlorophyllase enzyme and thereby reduced the amount of chlorophyll. Racuciu and Reanga have shown that nanoparticles in low amount (50-10 ml) increase levels of chlorophyll a, as main pigments up to $13 \%$ [29]. Generally, metallic nanoparticles are strong amplifiers of photosynthetic efficiency and this in parallel caused the absorption of light by chlorophyll to increase, it also causes the transfer of energy from chlorophyll to the nanoparticles [30] [31] [32]. Due to the decline of chlorophyll in the concentration of 7 grams per thousand nano zinc oxide compare to 4 grams per thousand nano zinc oxide, it appears that maybe the reduction in the amount of chlorophyll occurs because of prevention or degradation of the precursors of these pigments. Carotenoids are antioxidant compounds soluble in plant cells. These compounds through non-enzymatic route operate to reduce oxidative damage to the plant. Carotenoids are present in plast of plant tissues and in the environmental stress triggers oxidative stress, are responsible protecting photosynthetic tissues, especially chlorophyll. It seems that certain amount of zinc induce oxidative stress and causes synthesis of carotenoids. 


\subsection{Lipid Peroxidation}

Zinc increases the activity of lipoxygenase enzyme as the most important enzyme of lipoxygenase pathway and thus stimulates the process of membrane lipid peroxidation [33]. In research on mint plant, increase of membrane lipid peroxidation rate on the effect of zinc treatment can be proof of the theory that zinc causes induced oxidative stress in plants [33]. Plasma membrane lipid peroxidation and also organelles membrane such as chloroplast and mitochondria lead to the formation of malondialdehyde (MDA). Therefore MDA is considered as a biochemical indicator to determine the membrane damage by free radicals [34]. In this study, it appears that $\mathrm{Zn}$ has phytotoxic effect on membranes of rosemary leaf cells. Rosemary at low concentrations of zinc, by induction of synthesis of antioxidant compounds, overcomes on oxygen free radicals caused by oxidative stress (Figure 3 ).

\subsection{Proline}

Proline as the most stable amino acid is common in many plants and naturally accumulates in large amounts in response to the environmental stresses. In addition to its role as osmolyte, proline plays a role in the stabilization of micro-cellular structures such as membranes, proteins and destroys free radicals in stress situation. In terms of stress, plants may be compatible with the production of metabolites such as amino acid, antioxidant and hormones to counteract the effects of stress and continue growing. In fact, proline as a chemical chaperone, stabilize proteins natural form and inhibits disturbing the folding of enzymes [35]. In some reports, a correlation is shown between accumulation of proline and plant resistance to environmental stresses [36]. Research indicates that by increasing the concentration of zinc shoots, proline increases. In stress conditions, glutamate that is the precursor for the synthesis of chlorophyll and proline goes into proline production. Four reasons for the increase of proline during stress have been proposed that include: 1) stimulation of proline synthesis of glutamate; 2) reduce its exports through the phloem; 3) prevent oxidation during stress; 4) destruction and disorder in the process of protein synthesis [37]. A study about the impact of nano-zinc oxide on Parivash plant showed that by increasing the concentration of nano zinc oxide in nutrient solution, proline increased in the shoots [38]. In our study $6 \mathrm{~g}$ per thousand zinc and 4 and $7 \mathrm{~g}$ per thousand nano zinc oxide increased proline significantly.

\subsection{Soluble Sugar}

The findings of this study suggest increasing the concentration of soluble sugars in shoots impacts the treatment of zinc and nano zinc oxide. According to the statement, possibly increasing the concentration of soluble sugars in shoot can result in increasing transmission of soluble sugar to the root to maintain its vital functions and cell osmotic adjustment. In support of this analysis, some researchers stated that the increase of soluble sugars in stress conditions, in addition to 
maintaining osmotic potential, will be able to maintain carbohydrate stores for cell basal metabolism at an optimal level [39]. Baba Arab Abedi and colleagues reported drought stress, spraying of zinc and potassium increased chlorophyll, proline and soluble sugars on all leaves in stages of growth in safflower [40].

\subsection{Phenolic Compounds}

The total phenolic compounds in plants have been investigated in numerous studies. In research nutrition of zinc yielded significant increase in the concentration of phenolic compounds rosemary leaves. Although the specific reason for this increase has not been mentioned, but the role of zinc in use of carbon to produce phenolic compounds on the shikimic acid cycle and acetate can be one of the reasons for this increase [41]. In research on the mint plant, the content of phenolic compounds in the treated plants compared to control plants increased with increasing concentrations of Zn. Zinc induces oxidative stress and will lead to free radical production in the plant, the plant will lead with stress and overcome on these species, their non-enzymatic antioxidant defense system (vitamin E, carotenoids and phenolic compounds) will be enabled, phenolic compounds have important role in this action, and it reduces the amount of damages caused by it [41]. In this experiment, the concentration of zinc oxide nanoparticles increases the amount of phenolic compounds entire leaf. It seems that zinc oxide nanoparticles also have the effect of tension on the rosemary and plant defense system has been activated. Increase in the total phenol may be due to the role of phenolic antioxidant.

\subsection{Antioxidant Potential}

In a study with increasing concentration of zinc oxide nano-scale, zinc absorption was increased considerably. Because of the induced toxicity, plant growth parameters decreased and oxidative stress is induced in the plants. Plant to fight free radicals generated, is increased activity of antioxidant enzymes [38]. Results show that the main reason for the high level of phenolic compounds is antioxidant activity in some extracts, as according to the evidence there is a positive relationship between the amount of phenolic compounds and plants antioxidant power [42]. Phenolic compounds are efficient as hydrogen donors and act as an effective antioxidant [43]. With increasing concentrations of phenolic compounds due to the increasing number of hydroxyl groups in the reaction medium, the possibility of donating hydrogen to free radicals, followed by increased inhibition power of extract exists [44]. According to the above cases and the relationship between phenolic compounds and DPPH free radical scavenging power, it can be concluded that non-enzymatic antioxidant capacity in plant tissues has a close relationship with concentration of protective compounds such as anthocyanin, flavonoids and total phenols. In this experiment, the results of DPPH free radical scavenging ability corresponded to findings in the characters of flavonoids and total phenol concentration. So in terms of the use of zinc oxide 
nanoparticles, with a concomitant increase in flavonoids and phenolic compounds, in the whole leaf DPPH radical scavenging capacity was increased significantly. In other words nanoparticles of zinc oxide with stimulating plant immune system increased free radical scavenging capacity and therefore have a positive impact on rosemary. Some researchers indicated that dietary $\mathrm{Zn}$ supplementation in the nanoparticles form improved the growth performance of juvenile grass carp, Ctenopharyngodon idella as compare to oxide and sulfated form of $\mathrm{Zn}$ [45].

\subsection{Conclusion}

In conclusion, the use of various combinations of zinc for example zinc sulphate and or nano-zinc oxide increased antioxidant enzyme activity, with the knowledge that the majority of cellular areas have potential of production of reactive oxygen species caused by stress. The proline, membrane lipid peroxidation, soluble sugar and phenolic compounds increased in the treated plants. In this study, treatments could boost plant immune system, so it can be expected that the use of these treatments will improve the plant tolerance levels against a variety of stresses.

\section{Acknowledgements}

The authors sincerely appreciate the cooperation and generous assistance of the officials of Biology Laboratory of College of Sciences, Shiraz University and all the colleagues and friends who helped us during this research.

\section{References}

[1] Siavashi, K., Soleimani, R., Malakouti, M.J. (2004) Effect of Zinc Sulfate Application Times and Methods on Grain Yield and Protein Content of Chickpea in Rainfed Conditions. Iranian Journal of Soil and Water Research, 18, 42-49.

[2] Kuepper, G. (2003) Foliar Fertilization. www.attra.ncat.org

[3] Hemantaranjan, A. and Gray, O.K. (1988) Iron and Zinc Fertilization with Reference to the Grain Quality of Triticum aestivum. L. Journal of Plant Nutrition, 11, 1439-1450. https://doi.org/10.1080/01904168809363900

[4] Stampar, F., Hudina, M., Dolenc, K. and Usenik, V. (1998) Influence of Foliar Fertilization on Yield Quantity and Quality of Apple (Malus domestica borkh.). In: Anac, D. and Martin-Prével, P., Eds., Improved Crop Quality by Nutrient Management, Springer, Dordrecht, 91-94. https://doi.org/10.1007/978-0-585-37449-9_21

[5] Malakoti, M.J. and Tehrani, M.M. (2001) Effects of Micronutrients on the Yield and Quality of Agricultural Products. Micro-Nutrients with Macro-Nutrients. 2nd Edition, Tarbiat Modarres University Press, Tehran.

[6] Farahat, M.M., Soad Ibrahim, L.S. and El-Quesni, E.M. (2007) Response of Vegetative Growth and Some Chemical Constituents of Cupressus sempervirens L. to Foliar Application of Ascorbic Acid and Zinc at Nubaria. World Journal of Agricultural Sciences, 3, 496-502.

[7] Marschner, H. (1995) Mineral Nutrition of Higher Plants. 2nd Edition, Academic Press, New York. 
[8] Baybordi, A. (2006) Zinc in Soils and Crop Nutrition. Parivar Press, Tehran, p. 179.

[9] Alloway, B.J. (2008) Zinc in Soil and Crop Nutrition. 2nd Edition, IZA and IFA Brussels, Belgium and Paris, $114 \mathrm{p}$.

[10] Welch, R.M. (1995) Micronutrient Nutrition of Plants. Critical Reviews in Plant Sciences, 14, 49-82. https://doi.org/10.1080/07352689509701922

[11] Donaldson, K., Tran, L., Jimenez, L.A., Duffin, R., Newby, D.E., Mills, N., MacNee, W. and Ston, V. (2005) Combustion-Derived Nanoparticles: A Review of Their Toxicology Following Inhalation Exposure. Particle and Fibre Toxicology, 2, 10. https://doi.org/10.1186/1743-8977-2-10

[12] Mazaherinia, S., Astaraei, A.R., Fotovat, A. and Monshi, A. (2010) Nano Iron Oxide Particles Efficiency on $\mathrm{Fe}, \mathrm{Mn}, \mathrm{Zn}$ and $\mathrm{Cu}$ Concentrations in Wheat Plant. World Applied Sciences Journal, 7, 36-40.

[13] Handy, R.D., Von Der Kammer, F., Lead, J.R., Hassellov, M., Owen, R. and Crane, M. (2008) The Eco Toxicity and Chemistry of Manufactured Nanoparticles. Ecotoxicology, 17, 287-314. https://doi.org/10.1007/s10646-008-0199-8

[14] Wu, B., Huang, R., Sahu, M., Feng, X., Biswas, P. and Tang, Y.J. (2010) Bacterial Responses to $\mathrm{Cu}$-Doped $\mathrm{TiO}_{2}$ Nanoparticles. Science of the Total Environment, 408, 1755-1758. https://doi.org/10.1016/j.scitotenv.2009.11.004

[15] Yilmaz, A., Ekis, H. and Cakmak, I. (1997) Effect of Different Zinc Application Methods on Grain Yield and Zinc Concentration in Wheat. Plant Nutrition, 20, 461-471. https://doi.org/10.1080/01904169709365267

[16] Naraghy, M. (2003) Curative Flowers and Plants. Amir Kabir Press, Tehran.

[17] El-Rajoob, A.O., Massadeh, A.M. and Omari, M.N. (2008) Evaluation of Pb, Cu, Zn, $\mathrm{Cd}, \mathrm{Ni}$ and Fe Levels in Rosmarinus officinalis (Rosemary) Medicinal Plant and Soils in Selected Zones in Jordan. Environmental Monitoring and Assessment, 140, 61-68. https://doi.org/10.1007/s10661-007-9847-3

[18] Al Sereiti, M.R., Abu Amer, K.M. and Sen, P. (1999) Pharmacology of Rosemary (Rosmarinus officinalis Linn.) and Its Therapeutic Potentials. Indian Journal of EXperimental Biology, 37, 124-130.

[19] Arnon, D.I. (1959) Photosynthesis by Isolated Chloroplast IV Central Concept and Comparison of Three Photochemical Reactions. Biochemistry and Biophysics Acta, 20, 440-446.

[20] Bates, L.S. (1973) Rapid Determination of Free Proline for Water Stress Studies. Plant Soil, 39, 205-207. https://doi.org/10.1007/BF00018060

[21] Nelson, N. (1944) A Photometric Adaption of the Somogi Method for the Determination of Glucose. Journal of Biological Chemistry, 153, 375-380.

[22] Kim, K.T., Yoo, K.M., Lee, J.W., Eom, S.H., Hwang, I.K. and Lee, C.Y. (2007) Protective Effect of Steamed American Ginseng (Panax quinquefolius L.) on V79-4 Cells Induced by Oxidative Stress. Journal of Ethnopharmacology, 111, 443-445. https://doi.org/10.1016/j.jep.2007.01.004

[23] Shimada, K., Fujikawa, K., Yahara, K. and Nakamura, T. (1992) Antioxidative Properties of Xanthan on the Anti-Oxidation of Soybean Oil in Cyclodextrin Emulsion. Journal of Agricultural and Food Chemistry, 40, 945-948. https://doi.org/10.1021/jf00018a005

[24] Heath, R.L. and Packer, L. (1968) Photo Peroxidation in Isolated Chloroplast. I. Kinetic and Stochiometry of Fatty Acid Peroxidation. Archives Biochemistry and Biophysics, 125, 189-190. https://doi.org/10.1016/0003-9861(68)90654-1 
[25] Movahhedi Dehnavi, M. (2004) Effect of Foliar Application of Micronutrients (Zinc and Manganese) on the Quantitative and Qualitative Yield of Different Autumn Safflower Cultivars under Drought Stress in Isfahan. Ph.D. Thesis, Faculty of Agriculture, Tarbiat Modarres University, Tehran, $211 \mathrm{p}$.

[26] Cakmak, I. (2000) Possible Roles of Zinc in Protecting Plant Cells from Damage by Reactive Oxygen Species. New Phytology, 146, 185-205. https://doi.org/10.1046/j.1469-8137.2000.00630.x

[27] Lebedev, N. and Timco, P.M. (1998) Protochlorophyllide Photoreduction. Photosynthesis Research, 58, 5-23. https://doi.org/10.1023/A:1006082119102

[28] Behtash, F., Tabatabai, J., Malakoti, M., Sarvaradin, M. and Oostan, S.H. (2010) The Effect of Zinc and Cadmium on Growth, Chlorophyll, Photosynthesis, Cadmium Concentration in Red Beet. Journal of Soil Research, 24, 31-41.

[29] Racuciu, M., Calugaru, G.H. and Creanga, D.E. (2006) Static Magnetic Field Influence on Some Plant Growth. Romanian Journal of Physiology, 51, 245-251.

[30] Govorov, A.O. and Carmeli, I. (2007) Hybrid Structures Composed of Photosynthetic System and Metal Nanoparticles: Plasmon Enhancement Effect. Nano Letters, 7, 620-625. https://doi.org/10.1021/nl062528t

[31] Nadtochenko, V.A., Nikandrov, V.V., Gorenberg, A.A., Karlova, M.G., Lukashev, E.P., Semenov, A., Yu Bukharina, N.S., Kostrov, A.N., Permenova, E.P. and Sarkisov, O.M. (2008) Determination of Total Anthocyanin in Cranberries. Journal of Food Science, 33, 72-77.

[32] Mingyu, S., Xiao, W., Chao, L., Chunxiang, Q., Xiaoqing, L., Liang, C., Hao, H. and Fashui, H. (2007) Promotion of Energy Transfer and Oxygen Evolution in Spinach Photosystem II by Nano-Anatase $\mathrm{TiO}_{2}$. Biological Trace Element Research, 119, 183-192. https://doi.org/10.1007/s12011-007-0065-1

[33] Tripathi, B.N., Mehta, S.K., Amar, A. and Gaur, J.P. (2006) Oxidative Stress in Scenedemus sp. During Short and Long-Term Exposure to $\mathrm{Cu}$ and $\mathrm{Zn}$. Chemosphere, 62, 538-544. https://doi.org/10.1016/j.chemosphere.2005.06.031

[34] Smirnoff, N. (1995) Antioxidant Systems and Plant Response to the Environment. In: Smirnoff, N., Ed., Environment and Plant Metabolism: Flexibility and Acclimation, Bios Scientific Publishers, Oxford, 217-243.

[35] Solomon, A. and Beer, S. (1994) Effect of $\mathrm{NaCl}$ on the Aarboxylation Activity of Rubisco and Absence of Prolin Related Compatible Solute. Plant Physiology, 108, 1387-1394.

[36] Ashraf, M. and Foolad, M.R. (2007) Roles of Glycine Betaine and Proline in Improving Plant Abiotic Stress Resistance. Environmental and Experimental Botany, 59, 206-216. https://doi.org/10.1016/j.envexpbot.2005.12.006

[37] Llamas, A., Ullrich, C.I. and Sanz, A. (2000) Cadmium Effects on Transmembrane Electrical Potential Difference, Respiration and Membrane Permeability of Rice (Oryza sativa) Roots. Plant and Soil, 219, 21-28. https://doi.org/10.1023/A:1004753521646

[38] Amirjani, M.R., Askari, M. and Askari, F. (2014) Effect of Nano Zinc Oxide on Alkaloids, Enzymatic and Anti-Enzymatic Antioxidant Contents and Some Physiological Parameters of Catharantus roseus. Journal of Cell Tissue, 5, 173-183.

[39] Kollattukudy, P.E. (1984) Biochemistry and Function Ocutin and Suberin. Canadian Journal of Botany, 62, 2918-2933. https://doi.org/10.1139/b84-391

[40] Anees, M.A., Ali, A., Shakoor, U., Ahmed, F., Hasnain, Z. and Hussain, A. (2016) Foliar Applied Potassium and Zinc Enhances Growth and Yield Performance of Maize under Rainfed Conditions. International Journal of Agriculture \& Biology, 18, 1025-1032. https://doi.org/10.17957/IJAB/15.0204 
[41] Misra, A., Dwivedi, S., Srivastava, A.K., Tewari, D.K., Khan, A. and Kumar, R. (2006) Low Iron Stress Nutrition for Evaluation of Fe-Efficient Genotype Physiology, Photosynthesis, and Essential Monoterpene Oil(s) Yield of Ocimum sanctum. Photosynthtica, 44, 474-477. https://doi.org/10.1007/s11099-006-0054-1

[42] Muret, K., Sevgi, K., Sengul, K., Esra, U., Cemalettin, B. and Fedra, V. (2007) Biological Activities, Chemical Composition of Three Honeys of Different Types from Anatolia. Food Chemistry, 100, 526-534.

https://doi.org/10.1016/j.foodchem.2005.10.010

[43] Golluce, M., Sahin, F., Sokmen, M., Ozer, H., Daferea, D., Sokmen, N., Polissicu, M., Adiguzel, A. and Ozken, H. (2007) Antimicrobial and Antioxidant Properties of the Essential from (Mentha longifolia L. ssp. longifolia). Food Chemistry, 103, 1449-1456. https://doi.org/10.1016/j.foodchem.2006.10.061

[44] Sanchez-Moreno, C., Larrauri, J.A. and Saura-Calixto, F. (1999) Free Radical Scavenging Capacity and Inhibition of Lipid Oxidation of Wines, Grape Juices and Related Polyphenolic Constituents. Food Research International, 32, 407-412. https://doi.org/10.1016/S0963-9969(99)00097-6

[45] Faizl, H., Zuberi1, A., Nazir, S., Rauf, M. and Younus, N. (2015) Zinc Oxide, Zinc Sulfate and Zinc Oxide Nanoparticles as Source of Dietary Zinc: Comparative Effects on Growth and Hematological Indices of Juvenile Grass Carp (Ctenopharyngodon idella). International Journal of Agriculture and Biology, 17, 568-574. https://doi.org/10.17957/IJAB/17.3.14.446 